\title{
NOTES OF THE QUARTER.
}

(July, August, September, 1897.)

I. Notes and News.

Buddhaghosa's Samantapāsādikā.-We are glad to know that an edition in Sinhalese characters of this commentary on the Vinaya is being edited in Ceylon, by U.S. S. Dharmakirti. The first quarter of the work has already appeared.

\section{THE KING OF SIAM.}

His Majesty the King of Siam received at Taplow Court, Berkshire, on Monday, August 16, an address from the Royal Asiatic Society.

As the arrangements were made at a few hours' notice, it was only possible to communicate with those members of Council who reside in town, and of those many had already left London.

A deputation consisting of Mr. Ashburner, Professor Bendall, Mr. Robert Chalmers, Dr. Gaster, Dr. Legge, Dr. T. H. Thornton, Mr. Watters, and Professor Rhys Davids (Secretary) was introduced by Sir Raymond West (Vice-President), K.C.I.E., LL.D.

The Secretary read the following address :-

The Royal Asiatic Society of Great Britain and Ireland avails itself of the opportunity graciously afforded by your Majesty respectfully to address to you its felicitation on your presence in this country. 
The Society was founded half a century ago by those few of the gentlemen in British service in the East, and others, who shared a just admiration for the treasures of Eastern thought and literature, who perceived the serious disadvantage of our ignorance of Asiatic peoples, and who desired, as the rules of the Society state, "to facilitate intercourse with Eastern peoples by an accurate interpretation of their feelings, their customs, and their beliefs."

The Society, animated always by the sentiments which led to its foundation, regards with special gratification the advent to our shores of a sovereign who has been a constant friend of education and a distinguished patron of literature, and it begs to tender to your Majesty a most cordial welcome on this your first visit to England.

Your Majesty has shown, throughout your long and beneficent career, an earnest desire to make as many as possible of your princes and people intimately acquainted with the institutions, the habits, and the thoughts of the West, and will appreciate the desire of this Society that the dazzle of Western material prosperity may not blind them to the real value of the great thoughts in that ancient literature that has been preserved, through so many centuries, by their own Siamese scholars at home.

Your Majesty, yourself a scholar of wide attainments, has, in a manner eminently befitting the only Buddhist sovereign in the world, taken the best possible steps to ensure such a result, not only by your own example and precept, but also by ordering the publication, in the alphabet of the Siamese people, of the whole of the Sacred Books of the Buddhists. And this magnificent edition of the Three Pitâkas, edited with great learning and accuracy by Siamese scholars, will also be, by your Majesty's generous gifts, of the greatest assistance to those European scholars who are endeavouring to solve the important problem of the real historical meaning and value of that great religion of which your Majesty is the acknowledged head.

The attempt of European scholars, members of this Society and working together in the Pali Text Society, 
to accomplish a similar work for Europe would have failed at the very outset if it had not been for your Majesty's enlightened and sympathetic support. And for the Pali Text Society's now stately list of forty volumes, and its promise for the future, European scholars have to thank therefore, in the first place, your Majesty's generous patronage.

Before these works can be adequately understood in the West, before the philosophy, the ethics, and the history of Buddhism can be as well appreciated there as are those of Europe, the books must be translated and analyzed in European languages. In recognition of this your Majesty, in spite of the ever increasing claims upon your revenue, has generously contributed to the series of translations now being published in Oxford.

In all these respects your Majesty stands alone among Oriental Sovereigns. No other has shown so enlightened a sympathy with scholarship at home and abroad, or has done so much to promote that intimate knowledge and intellectual companionship which form the most lasting basis of mutual respect and sympathy between the East and West.

Endeavouring to the best of its ability to promote similar results, this Society cannot but regard with sincerest sympathy the career of a monarch who, in these and other ways, has made so beneficent a use of his exalted position. And it begs, while tendering to your Majesty its cordial thanks for great things done in the past, to wish your Majesty health and happiness during your present journey, and a long and prosperous life in the future.

On behalf of Lord Reay (President), and the Council and the Members of the Society,

(Signed)

RaYMond West

(Vice-President').

T. W. Rhys Davids

(Secretary). 
His Majesty, in reply, said :-

I assure you, gentlemen, that I am deeply touched by the address that has been read. It is especially gratifying to me that a Society, numbering among its members so many of the most distinguished scholars both in this country and in Europe, has called me a friend of education. That I have always striven, and shall strive, to be. Reference has been made to the edition of the Three Pitākas which I have had printed. I am glad to take this opportunity of saying that the work shall not stop there. It is important to print also the commentaries, and I have already made arrangements to have not only the Atthakathās but also the Tiikas printed. This will be done gradually. You will understand that a work of this magnitude cannot be done in a hurry. But the undertaking is already set on foot, and I hope that when we begin, and we shall begin soon, two or three volumes a year will appear, so that in the course of time the whole will be eventually printed. I thank you, gentlemen, and the Society whom you represent for your appreciation of what has been a pleasure to me to have been able to do in the past, and for your kind wishes for the future.

His Majesty then spent some time in conversation with the members of the deputation, and has since presented to the Society a large photograph of himself with his autograph signature upon it. 
Gold Medal.-The following subscriptions to the Gold Medal, which has been awarded to Professor E. B. Cowell, have been already received or promised :-

\begin{tabular}{|c|c|c|c|c|c|c|}
\hline & & & & & & \\
\hline The President, Lord Re & & & & & $\begin{array}{l} \pm \\
5\end{array}$ & $\begin{array}{l}s . \\
0\end{array}$ \\
\hline Mr. F. F. Arbuthnot & & $\cdots$ & $\cdots$ & $\cdots$ & 2 & 0 \\
\hline Mr. B. H. Baden-Powe & & $\cdots$ & $\cdots$ & $\cdots$ & 1 & 1 \\
\hline Mr. H. Beveridge & ... & $\cdots$ & $\cdots$ & ... & 1 & 1 \\
\hline Mr. E. L. Brandreth & ... & $\ldots$ & $\cdots$ & $\cdots$ & 1 & 1 \\
\hline r. E. G. Browne & $\cdots$ & $\cdots$ & $\cdots$ & $\cdots$ & 1 & \\
\hline r. R. Burn , ... & $\cdots$ & $\cdots$ & $\cdots$ & $\cdots$ & 1 & 1 \\
\hline Dr. o. Codrington & ... & $\cdots$ & $\cdots$ & $\cdots$ & 1 & 1 \\
\hline rofessor E. B: Cowell & ... & $\cdots$ & $\cdots$ & $\cdots$ & 5 & 0 \\
\hline Dr. R. N. Cust ．.. & ... & $\cdots$ & $\cdots$ & $\cdots$ & 1 & 1 \\
\hline Professor Donner ... & $\cdots$ & ... & $\cdots$ & $\cdots$ & 1 & 1 \\
\hline M. E. Grant Duff & .. & $\cdots$ & $\cdots$ & $\cdots$ & 4 & 0 \\
\hline Mr. J. F. Fleet $\ldots$ & $\cdots$ & $\cdots$ & $\cdots$ & $\cdots$ & 1 & 1 \\
\hline Mr. R. W. Frazer & ... & .. & $\cdots$ & $\cdots$ & 1 & 1 \\
\hline Dr. M. Gaster ～... & ... & ... & $\cdots$ & ... & 1 & 1 \\
\hline rs. Gibson & $\cdots$ & $\cdots$ & $\cdots$ & $\cdots$ & 1 & 1 \\
\hline Ir Frederick Goldsmid & $\cdots$ & $\cdots$ & $\cdots$ & $\cdots$ & 1 & 1 \\
\hline ajor-General Gosset & $\cdots$ & $\cdots$ & $\cdots$ & $\cdots$ & 1 & 1 \\
\hline x. R. Griffith $\quad \ldots$ & $\cdots$ & $\cdots$ & $\cdots$ & $\cdots$ & 1 & \\
\hline Mr. R. Heap $\quad$... & .. & $\cdots$ & $\cdots$ & $\cdots$ & 1 & 1 \\
\hline ir W. Wilson Hunter & $\cdots$ & $\cdots$ & $\cdots$ & $\cdots$ & 3 & 3 \\
\hline [r. W. Irvine $\quad \ldots$ & $\cdots$ & $\cdots$ & $\cdots$ & $\cdots$ & 1 & 1 \\
\hline Ir. H. C. Kay ... & .. & $\cdots$ & $\cdots$ & ... & 2 & 12 \\
\hline Mr. J. Kennedy $\ldots$ & $\cdots$ & $\cdots$ & ... & $\cdots$ & 1 & 1 \\
\hline His Highness Kerala $\mathrm{Va}$ & rma & ... & $\cdots$ & $\cdots$ & 2 & 0 \\
\hline r. F. W. Lawrence & $\ldots$ & ... & $\cdots$ & $\cdots$ & 1 & 1 \\
\hline r. G. W. Leitner & ... & ... & $\cdots$ & $\cdots$ & 1 & 1 \\
\hline Ir. Guy Le Strange & $\cdots$ & $\cdots$ & $\cdots$ & $\cdots$ & 1 & 1 \\
\hline Mrs. Lewis _.. & ... & $\cdots$ & $\cdots$ & ... & 1 & 1 \\
\hline Mr. W. McDouall & & $\cdots$ & $\cdots$ & $\cdots$ & 1 & 0 \\
\hline Professor D. Margoliou & & $\cdots$ & $\cdots$ & $\cdots$ & 1 & 1 \\
\hline r. C. J. Marzetti & $\cdots$ &.$\cdot$ & $\cdots$ & $\cdots$ & 1 & 1 \\
\hline Professor Barbier de $\mathrm{Me}$ & ynard & ... & $\cdots$ & $\cdots$ & 1 & 0 \\
\hline r. F. D. Mocatta & $\ldots$ & $\cdots$ & $\cdots$ & $\cdots$ & 5 & 0 \\
\hline Sir William Muir „.... & & $\cdots$ & $\cdots$ & $\cdots$ & 3 & 0 \\
\hline Professor F. Max Müll & & $\cdots$ & $\cdots$ & $\cdots$ & 2 & 0 \\
\hline Mr. R. A. E. Neil & & $\cdots$ & $\cdots$ & $\cdots$ & 1 & 1 \\
\hline Mr. W. J. Prendergast & $\ldots$ & $\cdots$ & $\cdots$ & $\ldots$ & 0 & 5 \\
\hline The Marquess of Ripon & $\cdots$ & $\cdots$ & $\cdots$ & $\cdots$ & 2 & 0 \\
\hline s. E'mile Senart & $\cdots$ & $\cdots$ & $\cdots$ & $\cdots$ & 2 & 0 \\
\hline Mr. R. Sewell ... & $\cdots$ & $\cdots$ & $\cdots$ & ... & 1 & 1 \\
\hline Mr. C. Tawney ... & $\ldots$ & $\cdots$ & $\cdots$ & $\cdots$ & 1 & 1 \\
\hline Lieut. -Colonel R. C. T & emple & $\cdots$ & $\cdots$ & $\cdots$ & 2 & 2 \\
\hline Dr. T. H. Thornton & 2 & & $\ldots$ & $\ldots$ & 1 & 1 \\
\hline His Highness the Mahā & räja of & Tra & core & $\cdots$ & 5 & 0 \\
\hline Mr. M. J. Walhouse & $\ldots$ & $\cdots$ & $\cdots$ & $\cdots$ & 1 & I \\
\hline & $\cdots$ & $\ldots$ & $\cdots$ & $\cdots$ & 1 & 1 \\
\hline Sir Raymond West & $\ldots$ & $\ldots$ & $\cdots$ & $\cdots$ & 3 & 0 \\
\hline Mr. A. N. Wollaston & $\cdots$ & $\ldots$ & ... & ... & 1 & 1 \\
\hline & & & & & & \\
\hline
\end{tabular}

